\title{
Stage IIIA Anal Canal Cancer AJCC v6 and v7
}

National Cancer Institute

\section{Source}

National Cancer Institute. Stage IIIA Anal Canal Cancer A/CC v6 and v7. NCI Thesaurus.

Code $C 5925$

Stage IIIA includes: (T1, N1, M0); (T2, N1, M0); (T3, N1, M0); (T4, N0, M0). T1: Tumor 2 $\mathrm{cm}$ or less in greatest dimension. T2: Tumor more than $2 \mathrm{~cm}$ but not more than $5 \mathrm{~cm}$ in greatest dimension. T3: T umor more than $5 \mathrm{~cm}$ in greatest dimension. T4: Tumor of any size that invades adjacent organ(s). N1: Metastasis in perirectal lymph node(s). N0: No regional lymph node metastasis. M0: No distant metastasis. (AJCC 6th and 7th Eds.) 